\title{
GULF OF MANNAR - A CORAL DOMINATED ECOSYSTEM IN DANGER
}

\section{GOLFO DE MANNAR - UN ECOSISTEMA CON DOMINANCIA DE CORAL EN PELIGRO}

\author{
S. Sambasivam and P. Subramanian \\ Centre of Advanced Study in Marine Biology \\ Annamalai University \\ Parangipettai - 608502 \\ Tamil Nadu, India
}

Sambasivam, S. and Subramanian, P. Gulf of Mannar - A Coral Dominated Ecosystem in Danger. Golfo de Mannar - un ecosistema con dominancia de coral en peligro. Ciencias Marinas 14(3): 39-50, 1988.

\section{ABSTRACT}

The "biologist's paradise" Gulf of Mannar is endowed with a variety of organisms including rare and endangered species. This bountiful denizen is duly recognized and declared a National Marine Park in the Nallathanni thevu, one among the 20 islands in the Gulf of Mannar Archipelago. This ecologically unique and pride area is approaching jeopardy owing to a proposal named "Sethusamudram Project". This paper attempts to analyse the feasible catastrophe evolved after implementing the project.

\section{RESUMEN}

El Golfo de Mannar, "paraíso de los bíologos", está dotado de una variedad de organismos que incluyen especies raras y en peligro de extinción. Este generoso lugar de organismos aclimatados está merecidamente reconocido, y ha sido declarado como Parque Marino Nacional en Nallathanni thevu, una entre veinte islas en el Archipiélago del Golfo de Mannar. Esta área de orgullo y ecológicamente única está próxima al peligro debido a una propucsta llamada "Proyecto Sethusamudram". Este estudio pretende analizar la posible catástrofe que evolucionaría después de implementar el proyccto.

\section{INTRODUCTION}

The Gulf of Mannar $\left(78^{\circ} 08^{\prime} \mathrm{E}\right.$ to $79^{\circ}$ $30^{\prime} \mathrm{E}$ and $8^{\circ} 35^{\prime} \mathrm{N} 109^{\circ} 25^{\prime} \mathrm{N}$ ) is unique for its biological wealth and some of the islands are a varietable biologist's paradise. The Gulf of Mannar marine province is situated between India and Sri Lanka. It runs on the Indian side, with its head from Pamban islands southwards up to Kanyakumari (Cape Comorin) to a distance of about 170 nautical miles. This is otherwise called Kilakarai channel.

After the dclimitation of the Exclusive Economic Zone (EEZ), the Indian part of the

\section{INTRODUCCION}

El Golfo de Mannar ( $78^{\circ} 08^{\prime}$ E, 790 E y $8^{\circ} 35^{\prime} \mathrm{N}, 9^{\circ} 25^{\prime} \mathrm{N}$ ) es único por su riqueza biológica, y algunas de las islas son un paraíso para los biólogos por su variedad. La provincia marina del Golfode Mannar está situada entre la India y Sri Lanka. Del lado de la India comienza desde Islas Pamban hacia el Sur hasta Kanyakumari (Cabo Comorin), a una distancia de aproximadamente 170 millas náuticas. También se le llama Canal Kilakarai.

Una vez delimitada la Zona Económica Exclusiva (ZEE), la parte del Golfo perteneciente a la India cubre aproximada- 
Gulf covers approximately an area of $10,500 \mathrm{~km}^{2}$ running southward and parallel to the mainland coastline, with an arc of 20 islands in this archipelago, starting from the northern most Pamban island to Tuticorin. "Sethusamudram Project", a project of deepening the existing shallow sea passage into an efficient shipping canal through Adam's Bridge. It will shorten the Indian Navigational route within its territorial limit (at present the Navigational route encircles Sri Lanka to reach ports of east coast from west coast or vice versa); this might be approved soon by the Central Goverment. This study analyzes the importance of this fragile ecosystem and the expected future effects after the approval of the proposed project, in addition it emphazises the need to protect this unique ecosystem.

\section{CORAL REEF FORMATIONS}

The coral reef rank among the most productive ecosystems. The calm, shallow waters of tropical oceans are characterized by the presence of reef building corals. The corals which form the structural framework of the reef are highly specific in their requirements for light, temperature, water quality, salinity and oxygen. The symbiotic zooxanthellae which live in their tissues have a maximum requirement of light and the sedentary life style of corals makes them vulnerable to siltation. Corals flourish best in temperatures of $25-29^{\circ} \mathrm{C}$ and rarely survive below $20^{\circ} \mathrm{C}$ or in very high temperatures. In general, they have slow growth rates, ranging from $2 \mathrm{~cm} / \mathrm{y}$ for the massive brain corals such as Diploria and Montastrea to $20 \mathrm{~cm} / \mathrm{y}$ for branching corals such as Acropora. Adverse environmental conditions may cause even slower growth rates, failure of the reproductive mechanism which results in the expulsion of the zooxanthella and death of entire coral colonies.

\section{SPECIES COMPOSITION}

In the Gulf of Mannar, fringing and patch coral reefs occur on the eastern side of the islands. The reef framework is complex. It forms the basis of a very elaborate and functional ecosystem. It could also support a series of ecosystems. The exploitation of the mente un área de $10,500 \mathrm{~km}^{2}$ y baja hacia el Sur y paralelamente a la línea de costa de tierra firme, con un arco de 20 islas en este archipiélago. Comienza desde la parte norte de la Isla Pamban hasta Tuticorin. El Proyecto Sethusamudram pretende hacer más hondo el paso de agua marina somera existente para convertirlo en un eficiente canal para barcos por el Puente de Adam. Este acortará la ruta de navegación de la India con su límite territorial (a la fecha la ruta de navegación rodea Sri Lanka para llegar a puertos de la costa este a la costa oeste o vice versa); ésto puede ser aprobado en breve por el Gobierno Central. Este estudio analiza la importancia de este frágil ecosistema y los esperados efectos futuros después de la aprobación del proyecto propuesto; además, enfatiza la necesidad de proteger este ecosistema único.

\section{FORMACION DE ARRECIFES DE CORAL}

Los arrecifes de coral figuran dentro de los ecosistemas más productivos. Las aguas someras tranquilas de oceános tropicales se caracterizan por la presencia de la formación de arrecifes de coral. Los corales que forman el marco estructural del arrecife son bastante específicos en sus requerimentos de luz, temperatura, calidad del agua, salinidad y oxígeno. La zooxanthellae simbiótica que vive en sus tejidos requiere un máximo de luz, y la vida sedentaria de los corales la hace vulnerable a enarenarse. Los corales florecen mejor en temperaturas de $25-29{ }^{\circ} \mathrm{C}$ y raramente sobreviven en temperaturas menores de $20^{\circ} \mathrm{C}$ $o$ en muy altas temperaturas. En general, tienen un crecimiento lento, con un promedio de $2 \mathrm{~cm} /$ a para corales cerebro masivos como Diploria y Montastrea y de $20 \mathrm{~cm} / \mathrm{a}$ para ramas de coral como en el caso de Acropora. Las condiciones ambientales adversas pueden causar un crecimiento más lento, fallas en el mecanismo reproductivo que resulta en la expulsión de zooxanthella y la muerte de colonias enteras de coral.

\section{COMPOSICION DE LAS ESPECIES}

En el Golfo de Mannar, las franjas y parches de coral aparecen en el lado este de las islas. La estructura de los arrecifes es compleja. Esta forma la base de un ecosistema muy elaborado y funcional, y a su vez puede 
coraline stones, is concentrated on the northern and western sides. Hence, the eastern side remains relatively free of human influence and interference (Issac Rajendran and Kanagaraj David, 1972).

There are about 120 species, belonging 33 genera of corals to the Gulf of Mannar (Gopinadha Pillai, 1971). Of these, 110 species grouped in 26 genera are hermatypic. The conspicuous species belong to the families Acroporidae, Poritidae and Faviidae. There are also reefs in the Palk Strait at Mandapam.

\section{UNIQUENESS OF A CORAL ECOSYSTEM}

The Gulf of Mannar with its islands provide a variegated, very interesting, heterogenous habitat for its denizens. The organisms, plants and animals seem to enjoy the closest intimacy th seawater and have accomplished this relationship to a remarkable degree of perfection.

The entire area is famous for pearl banks, sacred chank beds, algal resources, seagrass ecosystems, coral beds, mangrove vegetation, fishing, Protochordate beds (Balanoglossus and Ascidians), rare species of sea cow Dugong dugong, etc.

\section{IMPORTANCE OF CORAL REEFS}

In 1980 , the International Union for Conservation of Nature and Natural Resources (IUCN), identified coral reefs as one of the essential ecological processes and life-support systems, necessary for food production, health and other aspects of human survival and sustainable development.

1. They provide fish, molluscs and crustaceans, on which many coastal communitics in developing countries depend, and commercial fisheries often indirectly depend on reefs which provide nursery facilities for juveniles.

2. Reefs protect the coastline against waves and storm surge, preventing sea erosion and contributing to the formation of sandy beaches and sheltered harbours.

3. Reefs are the source of raw materials and potential genetic resources. For example, sustentar una serie de ecosistemas. La explotación de las piedras coralinas está concentrada a los lados Norte y Oeste. Por lo tanto el lado Este se conserva relativamente libre de la influencia e interferencia humana (Issac Rajendran y Kanagaraj David, 1972).

Hay aproximadamente 120 especies pertenecientes a 33 géneros de corales en el Golfo de Mannar (Gopinadha Pillai, 1971). De éstos, 110 especies agrupadas en 26 géneros son hermatípicas. Las especies más notables pertenecen a las familias Acroporidae, Poritidae y Faviidae. También hay arrecifes en el Estrecho de Palk en Mandapam.

\section{UN ECOSISTEMA DE CORAL UNICO}

El Golfo de Mannar, junto con sus islas, proporcionan un habitat diverso, muy interesante y heterogéneo para sus habitantes. Los organismos, plantas y animales parecen disfrutar de su intimidad con el agua de mar y han llevado a cabo esta relación con un notable grado de perfección.

El área completa es famosa por bancos de perla, bancos de "chank" sagrado, recursos de algas, ecosistemas de pasto, bancos de coral, vegetación de pantano, pesquería, ban$\cos$ de Protochordate (Balanoglossus y Ascidians), especies raras de manatí Dugong dugong, etc.

\section{IMPORTANCIA DE LOS ARRECIFES DE CORAL}

En 1980, la Unión Internacional para la Conservación de la Naturaleza y Recursos Naturales (UICN) nombró a los arrecifes de coral como uno de los procesos ecológicos esenciales y sistema de apoyo a la vida, necesario para la producción de alimento, salud y otros aspectos de sobrevivencia humana y como apoyo al desarrollo.

1. Los arrecifes proveen peces, moluscos y crustáceos de los cuales muchas comunidades costeras en países en desarrollo dependen, y también a menudo, de los arrecifes dependen indirectamente pesquerías comercialcs, los cuales proveen de facilidades de viveros para juveniles. 
corals and coral sand are used as building materials, stony corals are used to make lime and cements, black and red corals are used for jewellery, stony corals, shells and aquarium fishes are collected for a variety of decorative purposes.

4. Reef organisms produce highly active bio-compounds to deal with their crowded environment and many of these have antimicrobial, antileukemic, antitumor and a variety of other medicinal properties.

5. Tourism in many countries is based on reef-related activities and aesthetic appeal, and the recreational value of reefs is of increasing economic importance.

\section{HIGH TERTIARY PRODUCTION}

Coral reefs and associated communities in depths of less than $30 \mathrm{~m}$ cover about six million $\mathrm{km}^{2}$ on a global basis. Fisheries production may be quite high in coral reefs, and a production figure of $4-6$ tons $/ \mathrm{km}^{2} / \mathrm{y}$ of fish and crustaceans was reported by Munro (1984). Detailed studies show a still higher production of 8.7 tons $/ \mathrm{km}^{2} / \mathrm{y}$ for Apo Island and 16.5 tons $/ \mathrm{km}^{2} / \mathrm{y}$ for Sumilon Reef (both in The Philippines). In American Samoa, harvests of fish, gastropods and bivalves totalled to 18 tons $/ \mathrm{km}^{2} / \mathrm{y}$ down to a depth of only $8 \mathrm{~m}$. This estimate suggests a theoretical potential harvest of nine million tons/y from all coral reef areas. It is very high when compared with the current global fish production of 76 million tons $/ y$.

\section{EFFECTS OF THE SETHUSAMUDRAM PROJECT ON A CORAL REEF ECOSYSTEM}

Figure 1 depicts the proposed canal route across the Gulf of Mannar and Palk Bay. The objective of the project is to excavate a channel across Adam's Bridge to connect the Gulf of Mannar with Palk Bay in order to shorten and improve the sea route between the west and east coests of India. The sandstone coral reef in the sea between Dhanuskodi - Rameswaram and Thalaimannar (in Sri Lanka) is known as the Adan's Bridge. Through this channet ships up to 30 feet
2. Los arrecifes protegen la línea de costa contra el oleaje y surgencia de tormentas, preveen la erosión del mar y contribuyen a la formación de playas arenosas y puertos protegidos.

3. Los arrecifes son un recurso de materias primas y de recursos genéticos potencial. Por ejemplo, los corales y la arena de coral se usa en materiales de construcción, las piedras de coral se usan para hacer cal y cementos, los corales negros y rojos se usan en la joyería, las piedras de coral, las conchas y los peces de acuario se coleccionan para una gran variedad de fines decorativos.

4. Los organismos de los arrecifes producen biocompuestos altamente activos para protegerse de su muy concurrido ambiente y muchos de éstos tienen propiedades antimicrobiales, antileucémicas, antitumores y una gran variedad de otras propiedades medicinales.

5. El turismo en muchos países se basa en actividades relacionadas con los arrecifes y su apariencia estética y el valor recreacional de éstos es de una creciente importancia económica.

\section{ALTA PRODUCCION TERCIARIA}

Los arrecifes de coral y comunidades asociadas en profundidades menores de $30 \mathrm{~m}$ cubren cerca de seis millones de kilómetros cuadrados como base global. La producción de pesquerías puede ser alta en los arrecifes de coral. Una producción de 4 - 6 tons $/ \mathrm{km}^{2} / \mathrm{a}$ de peces y crustáceos fue reportada por Munro (1984). Estudios detallados muestran producciones aun mayores de 8.7 tons $/ \mathrm{km}^{2} / \mathrm{a}$ en la Isla de Apo y 16.5 tons $/ \mathrm{km}^{2} / \mathrm{a}$ en el arrecife Sumilon (ambos en Filipinas). En Samoa Americana, cosechas de peces, gastrópodos y bivalvos hacen un total de 18 tons $/ \mathrm{km}^{2}$ a una profundidad de $5610.8 \mathrm{~m}$. Esta estimación sugiere una cosecha potencial teririca de nueve millones de tons/a para todas las áreas de arrecifes; esta es muy alta comparada con la producción global actual de peces de 76 millones tons/a. 
Sambasivam, S. and Subramanian, P. - Gulf

\section{SETHU SAMUDRAM PROJECT}

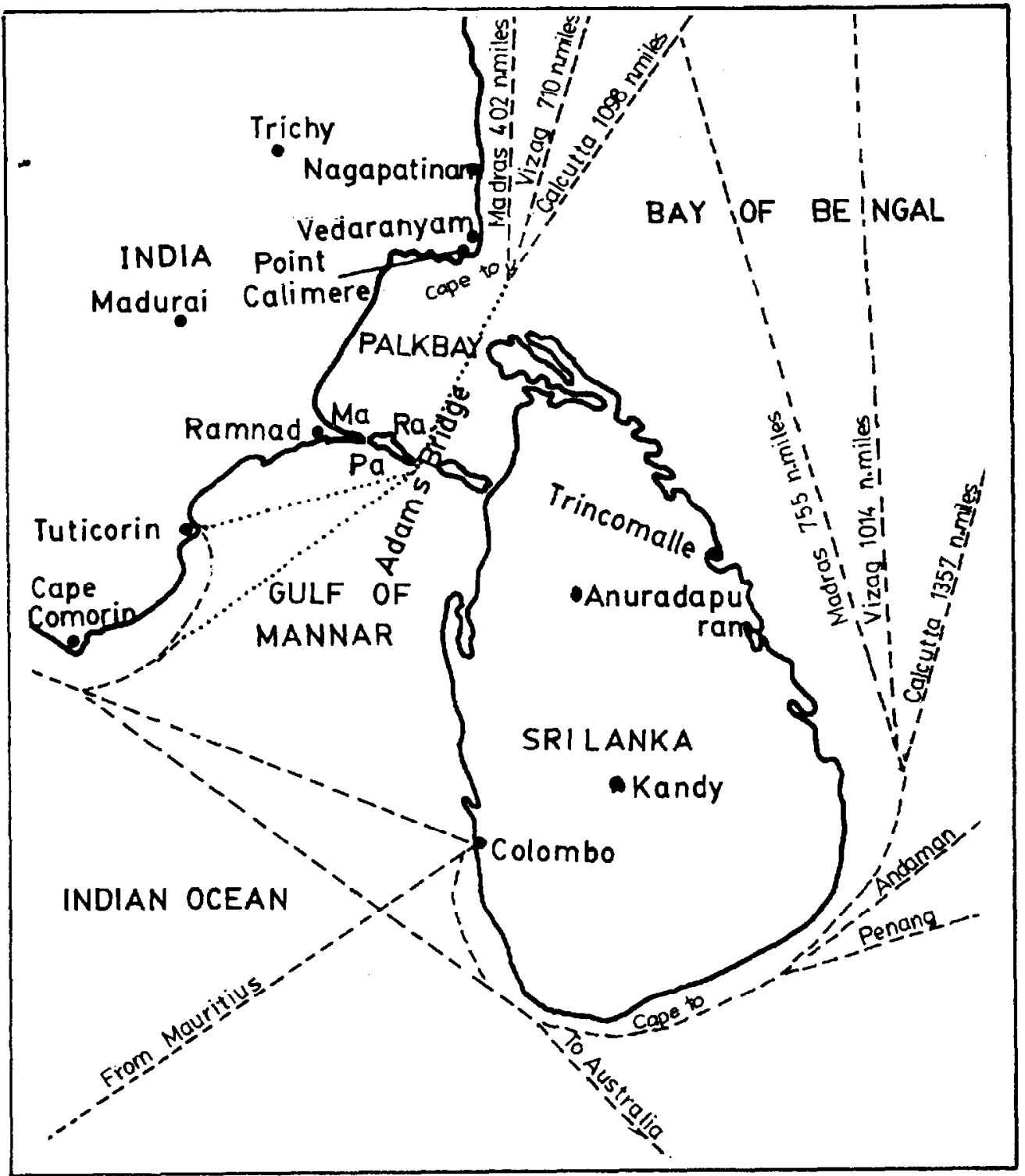

Figure 1. Map showing the proposed Sethusamudram (dotted lines) project in the Gulf of Mannar and Palk Bay rcgions.

Figura 1. Mapa que muestra la propuesta del proyecto Sethusamudram (línea punteada) en las regiones del Golfo de Mannar y Bahía Palk.

Symbols to denote respective places indicated against each.

Símbolos que muestran los respectivos lugares indicados.

$\mathrm{Ma}$ - Mandapam
$\mathrm{Ra}$ - Rameswaram

$\mathrm{Pa}$ - Pamban

$\mathrm{Ta}$ - Thalaimannar 
drought can navigate with safety and avoid going in a circuitous route around the south of Sri Lanka, which is less than 15 feet. It is highly impossible for any ship to negotiate the area, and ships from the west to the east coast have to sail around Sri Lanka. India does not have a continuous stretch of navigable route within its own territorial waters. This project offers the only adution for the problem. The project was insisted based on the grounds of efficiency and economy.

\section{CORAL EXCAVATION}

The project envisages excavation of a canal in the Rameswaram Island to connect the Palk Strait with the Gulf of Mannar. It reduces the distances from Cape Comorin for all traffic from the west to Madras, Visakhapatnam and Calcutta by 353,295 and 259 nautical miles respectively. Out of several alignments considered the Mandapam and Rameswaram alignments were found to be feasible. Of these two, Rameswaram is shorter and cheaper than the Mandapam alignment, the estimated costs of which are 55.6 and 37.5 crores rupees respectively. It was earlier expected that a net revenue of Rs. 1.62 crores would be derived within a year or two after functioning of the canal, mostly in foreign exchange. It is definitely higher now in view of the esoalation of costs.

\section{MERITS AND DEMERITS OF THE PROJECT}

\section{Merits}

1. Recently the USA is seeking a base in Trinoomalle in Sri Lanka. Therefore, it could be a potential threat for ships going via Sri Lanka in the event of a military operation. The recent Indo-Sri Lanka accord to solve this problem mostly.

2. Once the project is completed it would be possible to provide berthing facilities for international vessels at Tuticorin, which would set the pace for rapid economic development of the backward areas of Ramanathapuram and Tirunelveli areas of Tamil Nadu.

\section{EFECTOS DEL PROYECTO SETHUSAMUDRAM EN UN ECOSISTEMA DE ARRECIFES DE CORAL}

La Figura 1 representa la ruta del canal propuesto que cruza del Golfo de Mannar a la Bahfa Palk. El objetio del proyecto es excavar un canal atravesando el Puente de Adam para conectar el Golfo de Mannar con la Bahía Palk para acortar y mejorar la ruta por mar entre las costas oeste y este de la India. El arrecife de arena de coral en el mar entre Dhanuskodi-Rameswaram y Thalaimannar (en Sri Lanka) se conoce como el Puente de Adam. Por medio de este canal, los barcos de hasta 30 pies pueden navegar con seguridad y evitar una ruta indirecta alrededor del sur de Sri Lanka, la cual es menor a 15 pies. Es casi imposible para cualquier barco negociar en el área, y los barcos de las costas oeste y este tienen que navegar alrededor de Sri Lanka. La India no tiene tramos contínuos de ruta navegable en sus propias aguas territoriales; este proyecto ofrece la única solución al problema. Se ha insistido en el proyecto en base a la eficiencia y economía.

\section{EXCAVACIONES DE CORAL}

El proyecto planea excavaciones para abrir un canal en la Isla Rameswaram y conectar el Estrecho de Palk con el Golfo de Mannar. Esto reduce las distancias para todo el tráfico del Oeste desde Cabo Comorin hasta Madras, Visakhapatnam y Calcuta, 353, 295 y 259 millas náuticas respectivamente. Entre varias vías rectas, se encontró que las de Mandapam y Rameswaram son las más probables. De estas dos, Rameswaram es más corta y más económica que la de Mandapam; el costo estimado es de 55.6 y 37.5 crores rupias respectivamente. Anteriormente se esperaba que se obtendría un ingreso neto de Rs. 1.62 crores en un año o dos después del funcionamiento del canal, principalmente en moneda extranjera. Es definitivamente más alto ahora en vista del incremento de costos.

\section{CONVENIENTES E INCONVENIENTES DEL PROYECTO}




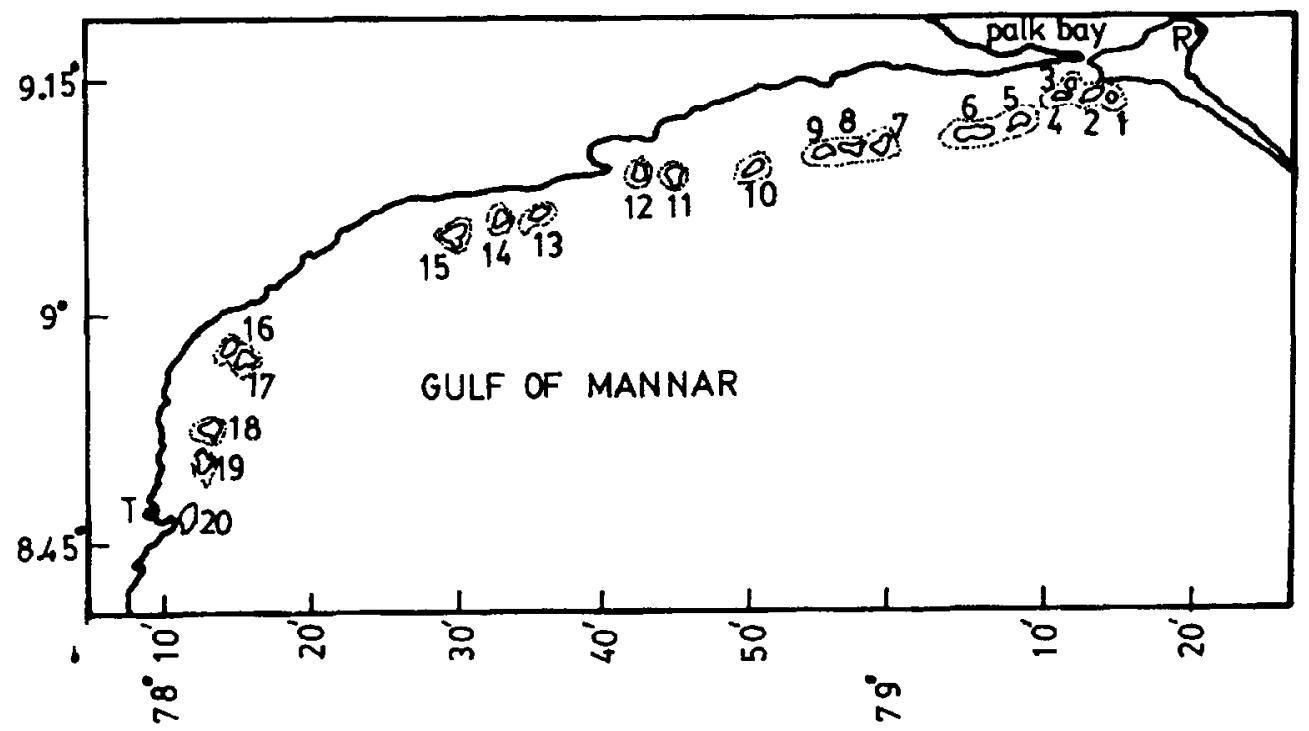

Figure 2. Map showing the islands in the Gulf of Mannar and the coral reefs in Palk Bay.

Figura 2. Mapa que muestra las islas en el Golfo de Mannar y los arrecifes de coral en la Bahía Palk.

1. Shingle tivu a

2. Krusadai tivu

3. Pullivasal tivu

4. Pulli tivu

5. Manauli tivu

6. Musal tivu

7. Mulli tivu

8. Thalai tivu

9. Talayari tivu

10. Appa tivu
11. Poovarasanpatti tivu

12. Anaipaar tivu

13. Nallathanni tivu

14. Puzhukuni

15. Upputanni tivu

16. Velangu challi tivu

17. Karai challi tivu

18. Karsewar tivu

19. Van tivu

20. Hare island (Pandyan tivu)

Symbols to denote respective places indicated against each.

Símbolos que muestran los respectivos lugares indicados.

T - Tuticorin
M - Mandapam
R - Rameswaram

a Tivu means islands

a Tivu significa isla 
3. The execution of the project would provide abundant employment opportunities to one of the most backward areas of the country viz. Ramanathapuram.

\section{Demerits}

1. Based on the ecological point of view, destruction is very easy and once the uniqueness of the ecosystem is disturbed or destroyed it will not be replaced soon. Generally it would take 100-200 or even more years for the recolonization of animals or the ecosystem.

2. Organisms which are present inside and above the substratum (meio and epifauna) including the commercial fishery will be affected by pollution due to continuous operation of the vessels.

3. The current pattern might change the nature of the fishery wealth especially in the case of migratory organisms.

4. Sca erosion will be more if a canal is developed. The reef protects the shore and beach against erosion and wave action.

5. The existence of the shallow areas naturally act as a defensive mechanism by preventing the entry of foreign fleets into our territorial waters.

6. Rare organisms (fauna and flora) of highly biological and economic importance will be disrupted and perhaps will not be replaced.

7. The existing clear water will be soon converted into turbid, silty and polluted water.

8. India is famous for the production of pearls and chanks. Once the canal is made, it would affect the above and other coexisting communities one after another, starting from pearl and chank beds, seagrass and algal beds, mangrove vegetation and their associated fauna and flora, including the commercial fishery and their dependent fisherfolk, since they are inseparably interrelated.

\section{Convenientes}

1. Recientemente los Estados Unidos pretende instalar una base en Trinoomalle, Sri Lanka; ésto podría ser una amenaza potencial para los barcos que van vía Sri Lanka en caso de una operación militar. $\mathrm{El}$ reciente tratado Indo-Sri Lanka acordó resolver este problema.

2. Una vez que el proyecto se completara sería posible ofrecer a buques internacionales facilidades para atracar en Tuticorin, lo que daría lugar a un rápido desarrollo económico en las áreas traseras de Ramanathapuram y Tirunelveli en Tamil Nadu.

3. La ejecución del proyecto proporcionaría abundantes oportunidades de trabajo a una de las áreas mas atrasadas del país del visir Ramanathapuram.

\section{Inconvenientes}

1. Desde el punto de vista ecológico, la destrucción sería muy sencilla y una vez que el ecosistema se perturbara o destruyera, no se reemplazaría rápidamente. Generalmente tomaría de 100 - 200 ó hasta más años para recolonizar de animales o restaurar el ecosistema.

2. Los organismos que se presentan dentro y sobre el sustrato (meioy epifauna), incluso los de la pesquería comercial serían afectados por la contaminación debido a las continuas operaciones de los buques.

3. El presente patrón podría cambiar la naturaleza de la riqueza pesquera, especialmente en el caso de organismos migratorios.

4. La erosión marina se incrementaria si se desarrollara un canal. Los arrecifes protegen a la orilla y a la playa contra la erosión y la acción del oleaje.

5. La existencia de las áreas someras actúan de forma natural como un mecanismo de defensa para prevenir la entrada de flotas extranjeras en nuestras aguas territoriales. 
9. The estimated cost of the project was now Rs. $110 /$ - crores and it was expected to yield a revenue of Rs. 2.90 crores annually. One could easily work out the revenue recovery of a project within 20 or 30 years. Therefore, the project will pay back the full capital investment in the next three decades. But, will they repay the loss of nature or ecological and biological wealths?

10. The economically and technologically thinking experts quite often ignored the fact that living organisms react differently to external influences. Their internal processes and relationships with environment are only partly understood when a certain kind of influence is enforced on an organism. Its reaction is not precisely predictable.

\section{CONCERN FOR PRIORITY ASPECTS}

1. The coastal area development includes activities such as filling to provide sites for industry, housing, recreation, extraction of lagoon sand for use in construction and dredging to create harbours, ports and marinas. Such activities increase turbidity, alter water circulation and even upset the entire ecosystem.

2. Recently, the Tamil Nadu salt corporation has set up a plant near the islands on the mainland for the production of salt, salt based chemicals and byproducts. Organic pollution and sewage lead to eutrophication and smothering the corals by algae. Such pollution caused almost total destruction of the corals.

3. Coral mining is having a serious effect in many countries including India, Sri Lanka, Maldives, Indonesia, Sabah and The Philippines. The removal of large portions of the reef for industrial purposes leads to beach erosion.

4. Smothering of the coral polyp by siltation causes oxygen depletion, and the recolonization by plannular larvae is inhibited by silty substrates.

\section{Mineral exploration.}

6. Military activities.
6. Los organismos raros (fauna y flora) de alta importancia biológica y económica se afectarían y probablemente no se podrían reemplazar.

7. El agua cristalina existente pronto se convertiría en agua turbia, enlodada y contaminada.

8. La India es famosa por la producción de erlas y "chanks". Una vez que se construyera el canal éstas se verían afectadas así como otras comunidades coexistentes, empezando por bancos de perlas y de "chank", pastos marinos y estratos de algas, vegetación de pantanos y su fauna y flora asociada, incluyendo la pesquería comercial y los que dependen de ella, ya que están íntimamente relacionados.

9. El costo estimado del proyecto fue de Rs. $110 /$ - crores, y se esperaría devengar un ingreso de Rs. 2.90 crores anuales. Se puede estimar fácilmente la recuperación del ingreso de un proyecto a 20 ó 30 años. Por lo tanto, el proyecto recuperaría el capital total de inversión en las próximas tres décadas. Pero ise pagaría la pérdida de la naturaleza o la riqueza ecológica y biológica?

10. Los expertos en economía y tecnología ignoran a menudo el hecho de que los organismos vivientes reaccionan diferente a la influencia externa. Sus procesos internos y su relación con el ambiente cuando algún tipo de influencia se les impone se comprende sólo parcialmente; su reacción no se puede predecir con precisión.

\section{PREOCUPACION POR LOS ASPECTOS PRIORITARIOS}

1. El desarrollo del área costera incluye actividades que satisfacen las necesidades, tales como proporcionar sitios para la industria, viviendas, recreación, extracción de arena de laguna para usar en la construcción y dragado para construir muelles, puertos y marinas. Dichas actividades aumentan la turbidez del agua, alteran su circulación $y$ perturban al ecosistema entero. 
7. Intensive recreational activities.

8. Damaging fishery resources.

9. Over exploitation of reef species.

\section{CONCLUSIONS}

Thereforc, the Scthusamudram projcet in the Gulf of Mannar and Palk Bay areas should not be cleared. Biological and aquarium fish collections should be allowed only in designated areas for a regulated quantity. Traditional fishing will be allowed only in specified areas. Bottom trawlers should not be permitted to operate over coral reefs. Anchoring should be prohibited over shallow areas of fragile coral growth.

\section{REEF MANAGEMENT}

\section{A. National marine parks and protected areas:}

Reef management through a system of Biosphere Reserves or conservation can help stop further degradation, facilitate the recovery of devastated areas, protect breeding stocks and improve recruitment in neighbouring areas and maintain the sustainable utilization.

Realizing the importance of the uniqueness of this ecosystem, the National Man and Biosphere Committee of the Department of Environment, Govt. of India, identified and sanctioned a Project Document preparation on the Gulf of Mannar. Under this the entire area was surveyed including the fauna and flora of 20 islands and a report with necessary suggestions were submitted to the Indian Man and Biosphere Committee (Prof. K. Krishnamurthy, Project Document 5, 1984).

Recently the Nall Thanni Theevu has been selected by the Centre for the Creation of National Marine Park in order to protect the fragile ecosystem. The island also sustains a remarkable variety of marine life, algae, starfish, sea-cucumber, crabs, etc.

However, as pointed out in the World Conservation Strategy, marine ecosystems are
2. Recientemente, la compañía de sal de Tamil Nadu ha instalado una planta en tierra firme cerca de las Islas para la producción de sal, químicos basados en sal y productos relacionados. La contaminación orgánica y las aguas residuales llevan a la eutrificación y asfixia de los corales por algas. Dicha contaminación causó la destrucción casi total de los corales.

3. El minado de coral ha ocasionado serios efectos en varios países como la India, Sri Lanka, Maldivias, Indonesia, Sabah y Las Filipinas. La remoción de grandes porciones de arrecifes para fines industriales ocasiona la erosión de las playas.

4. La asfixia del coral pólipo por enarenamiento ocasiona agotamiento de oxígeno, y la recolonización por medio de larvas planulares se inhibe por sustratos arenosos.

5. Exploración mineral.

6. Actividades militares.

7. Actividades recreativas intensas.

8. Daño a recursos pesqueros.

9. Sobreexplotación de especies de arrecife.

\section{CONCLUSIONES}

El proyecto Sethusamudram en las áreas del Golfo de Mannar y Bahía Palk no debería autorizarse. Las colectas biológicas y los peces de acuario se deberían permitir sólo en áreas designadas y por una cantidad regulada. La pesca tradicional sólo se debería permitir en áreas específicas. Las artes de arrastre de fondo no se deberían permitir en zonas de arrecifes de coral. El anclaje se debería de prohibir en áreas someras de crecimiento de coral frágil.

\section{ADMINISTRACION DE LOS ARRECIFES}

\section{A. Parques Marinos Nacionales $\mathrm{y}$ áreas protegidas}

La administración de arrecifes, a través de un sistema de Reservas de la Biósfera o de la conservación, puede ayudar a frenar una 
at present poorly represented in protected areas. Only three (Great Barrier Reef, Aldabra, Everglades) of the 50 World Heritage sites and five (Atoll de Taiaro, Malindi-Wata$\mathrm{mu}$, Virgin-Islands, Fort Jefforson, Puertayalora) of the 226 Man and the Biosphere Reserves contain reefs. Of the 1,162 National Parks on the U.N. list, probably only about 100 include or are adjacent to reefs (Wells, 1985). In addition, many of the designated coral reef reserves are not yet properly managed. Enforcement of park regulations is often arduous, as unlike terrestrial reserves, there is no way of erecting fences to keep wanderers away. Besides, protected areas have often never been surveyed and may not protect the most important reef areas.

\section{B. Environmental education:}

Although the reefs are over exploited in some areas, still in many other places they are under-utilised and constitute a valuable resource. Therefore, people should be educated about the importance and optimum exploitation of coral reefs. Education programme in schools and villages particularly in Thanjavur, Pudukkottai, Ramanathapuram and Tirunelveli districts of Tamil Nadu will go a long way in enabling the people to understand the importance of their reef resources, leading to improved enforcement of planning, control and regulations.

\section{ACKNOWLEDGEMENTS}

Thanks are due to $\mathrm{K}$. Krishnamurthy and the Director, CAS in Marine Biology, Parangipettai for facilities and UGC, New Delhi for financial assitance.

\section{LITERATURA CITADA}

Bulletin of the Madras Government Museum (1927) The Littoral Fauna of Krusadai Island in the Gulf of Mannar with Appendices on the Vertebrates and Plants by Various Authors, New series - National History Section, Vol. I, No. 1. Printed by the Superintendent Govt. Press. Madras, $196 \mathrm{pp}$. futura degradación, a facilitar el recuperamiento de áreas devastadas, a proteger depósitos de criadero y mejorar el reclutamiento en áreas vecinas y a mantener la utilización apropiada de estas áreas.

Dándose cuenta de la importancia de este ecosistema único, el Comité Nacional del Hombre y la Biósfera del Departamento del Ambiente, Gobierno de India, identificó y sancionó la preparación del proyecto de un documento en el Golfo de Mannar. Se investigó el área completa, inclusive la fauna y flora de 20 islas y se sometió un reporte con las sugerencias necesarias al Comité de la India para el Hombre y la Biósfera (Prof. K. Krishnamurthy, Documento del Proyecto 5, 1984.).

Recientemente el Nall Thanni Theevu ha sido seleccionadopor el Centro de Creación de Parques Marinos Nacionales para proteger el frágil ecosistema. La isla también mantiene una notable variedad de vida marina, algas, estrellas de mar, pepinos de mar, cangrejos, etc.

Sin embargo, como se señaló en la Estrategia de la Conservación Mundial, actualmente los ecosistemas marinos están pobremente representados en áreas protegidas. Unicamente tres (Great Barrier Reef, Aldabra, Everglades) de 50 sitios de Patrimonio Mundial y cinco (Atoll de Taiaro, Malindi-Watamu, Islas Vírgenes, Fuerte Jefforson, Puertayalora) de 226 Reservas del Hombre y la Biósfera contienen arrecifes. De los 1,162 Parques Nacionales en la lista de la ONU, probablemente sólo cerca de 100 contienen o están adyacentes a arrecifes (Wells, 1985). Además, muchas de las reseivas cie arrecifes de coral designadas no son todavía adecuadamente administradas. La aplicación de las regulaciones de los parques es a menudo complicada en comparación a las reservas terrestres. No hay forma de construir bardas para alejar a vagabundos. Por otro lado, las áreas protegidas rara vez son investigadas y no se han protegido las áreas de arrecifes más importantes. 
Gopinadha Pillai, C.S. (1971) Composition of the Coral Fauna of the Southeastern Coast of India and the Laccadives. In: Regional Variation in Indian Ocean Coral Reefs, (eds.) D.R. Stoddart and C.M. Yonge, published for the ZoologicalSociety of London, Academic Press, London, p. 301-328.

Issac Rajendran, A.D. and Kanagaraj David (1972) A Preliminary Under-Water Survey of the Extent of the Coral Reefs in and Around some of the Islands in Gulf of Mannar. Proc. Symp. on Corals \& Coral Reefs. Marine Biological Association of India, Mandapam, Camp., p. 231-238.

Munro, J.L. (1984) Coral Reef Fisheries and World Fish Production. ICLARM Newsletter, 7(4):3-4.

Subramanian, P., Sambasivam, S. and Krishnamurthy, K. (1985) Structural Components of some Algal Beds among Coral Islands, Gulf of Mannar, South India. 5th Intn. Coral Reef Congress, Tahiti, 27th May-1st June, 1985 (Abstract only, No. 366).

Wells, S.M. (1985) What is Happening to Coral Reefs? ICLARM Newsletter, 8(1):6-8.

\section{B. Educación ambiental}

A pesar de que los arrecifes son sobreexplotados en algunas áreas, en muchos otros lugares aún son subutilizados y constituyen un recurso valioso. Por lo tanto, se debería de educar a la gente sobre la importancia y la óptima explotación de los arrecifes de coral. Los programas de educación en escuelas y pueblos, particularmente de Thanjavur, Pudukkottai, Ramanathapuram y Tirunelveli, distritos de Tamil Nadú, serán de mucha importancia para hacer entender a la gente la importancia de los recursos de sus arrecifes, resultando en una mejoŕa de la aplicación de regulaciones de planeación y control.

\section{AGRADECIMIENTOS}

Se agradece a K. Krishnamurthy y a Parangipettai, Director de CAS en Biología Marina, por las facilidades otorgadas, y a la UGC, Nueva Delhi, por el apoyo económico.

Guadalupe González tradujo este artículo al español. 